\title{
Pulmonary artery aneurysms in Behçet disease
}

\author{
Aneurismas de artérias pulmonares na doença de Behçet
}

Shi-Min Yuan

\begin{abstract}
Pulmonary artery aneurysms (PAAs) are the most common type of pulmonary involvement in Behçet's disease. However, the relationships between clinical features and prognosis have not been sufficiently evaluated. This article describes the results of a comprehensive review, revealing that PAAs have a predilection for hemoptysis manifestations, increased dimensions, right lower lobar location, multiplicity and concurrent intramural thrombus formation. Surgical intervention was needed in one third of patients. Patients with massive hemoptysis and PAA rupture warranted emergency operations. Conservatively treated patients were prone to PAA progression; interventional embolization was associated with higher risks of recurrence and reintervention for PAAs; and surgically treated patients exhibited the highest mortality rates. In conclusion, PAAs in Behçet's disease are characterized by a predilection for hemoptysis manifestations, right lower lobar location, multiplicity, and concurrent intramural thrombus formation. Both the condition itself and the surgical operations it warrants are linked with high mortality due to PAA hemorrhage.
\end{abstract}

Keywords: hemoptysis; therapeutic embolization; vasculitis.

\begin{abstract}
Resumo
Os aneurismas das artérias pulmonares (PAA) são as manifestações mais comuns dos pulmões na doença de Behçet. No entanto, as relações entre as características clínicas e o prognóstico ainda não foram devidamente explicadas. O objetivo do presente artigo foi fazer uma ampla revisão da literatura sobre esta questão. As fontes de dados contaram com uma ampla revisão bibliográfica dos anos de 1990 a 2013, sobre os seguintes temas: doença de Behçet, síndrome de HughesStovin, aneurisma de artéria pulmonar e pseudoaneurisma da artéria pulmonar. Os PAA evoluíram com predileção por hemoptise, aumento de dimensões, localização no lobo inferior direito, multiplicidade e formação de trombo intramural. A intervenção cirúrgica foi necessária em um terço dos pacientes. O tratamento cirúrgico emergencial foi indicado na vigência de ruptura do PAA e de hemoptise maciça. Os pacientes tratados conservadoramente evoluíram com propensão para a progressão do PAA. A embolização dos PAA foi associada a uma taxa maior de recidiva e de reintervenção. Houve diferença significativa entre os grupos quanto às taxas de mortalidade, tendo o grupo do tratamento cirúrgico apresentado a maior taxa. Dentre as variáveis citadas, a hemoptise, o envolvimento da artéria lobar e a ruptura do PAA foram fatores preditivos de maior risco de mortalidade. Houve diferenças significativas nas taxas de mortalidade entre os pacientes cirúrgicos e intervencionistas, e entre os três grupos de pacientes: cirúrgico, intervencionista e conservador. Os pacientes tiveram uma sobrevida global de 61,7\% em um seguimento médio de 22,5 meses. Os PAA, na doença de Behçet, apresentaram as seguintes predileções: tendência a hemoptise, multiplicidade, localização no lobo inferior direito e presença de trombos intramurais. As rupturas e hemorragias dos PAA, aliadas ao necessário tratamento cirúrgico emergencial, resultaram no aumento de mortalidade destes pacientes.
\end{abstract}

Palavras-chave: hemoptise; embolização terapêutica; vasculite. 


\section{INTRODUCTION}

In Behçet's disease, pulmonary involvement is uncommon, with a prevalence of less than $5 \%{ }^{1}$ Pulmonary artery aneurysms (PAAs) are the most common form of pulmonary involvement in Behçet's disease, followed by pulmonary artery thrombosis, pulmonary infarction and pulmonary parenchymal disorders. ${ }^{2}$ Thrombosis usually develops as a consequence of the underlying extensive vasculitis. ${ }^{3,4}$ Currently, pulmonary artery aneurysms are the second most common type of arterial involvement in Behçet's disease, preceded by aortic aneurysms. ${ }^{2}$ Hemoptysis of varying degrees up to $500 \mathrm{ml}$ was the most common symptom of PAAs, observed in $79 \%$. ${ }^{2,5}$ Hemoptysis can sometimes be massive and lethal, when PAAs rupture into the adjacent bronchus. ${ }^{6}$ Other manifestations of PAA include cough, dyspnea and chest pain. ${ }^{6}$

Hughes-Stovin syndrome is a combination of pulmonary artery thrombosis and aneurysms with peripheral thrombophlebitis and is considered an incomplete variant of Behçet's disease. Characterized by an association of multiple PAAs and peripheral venous thrombosis, Hughes-Stovin syndrome shares identical pulmonary manifestations with Behçet's disease. ${ }^{7}$ Thrombophlebitis, formation of large pulmonary and/or bronchial aneurysms and aneurysmal rupture leading to massive hemoptysis and death are the three phases of the clinical paradigm of Hughes-Stovin syndrome. ${ }^{8}$

Previous reports have described the clinical features of PAAs in Behçet's disease. ${ }^{2,9-11}$ However, the relationships between the clinical features and prognosis have not been sufficiently evaluated and thus remain to be identified. This article presents a comprehensive literature review of the subject.

\section{MATERIALS AND METHODS}

\section{Search strategies}

A comprehensive literature search was conducted on MEDLINE, Highwire Press and Google for the year range 1990-2013. The search terms included "Behçet's disease", "Hughes-Stovin syndrome" and "pulmonary artery aneurysm" or "pulmonary artery pseudoaneurysm". Data were extracted from the text, figures and/or tables, with details of the study population, demographics, duration of Behçet's disease, characteristics of PAAs, management strategies and pertinent indications, follow-up duration and main outcomes (survival, recurrence, complication, reintervention and mortality).

\section{Definitions}

Severity of hemoptysis was defined as: mild $<5 \mathrm{ml}$ in 24 hours; moderate $5-600 \mathrm{ml} / 24$ hours and massive $>600 \mathrm{ml} / 24$ hours, or $100 \mathrm{ml} /<24$ hours to $1000 \mathrm{ml} /$ several days, or $>50 \mathrm{ml}$ per expectoration, ${ }^{12}$ and sudden recurrent massive hemoptysis was defined as life-threatening hemoptysis. Onset of action was defined as the time for the immunosuppressive agents to take effect (including symptom relief, decreased inflammatory mediators, reduced pulmonary or intracardiac thrombus and reduced PAA) after administration; and cure time was the time interval from drug administration to complete resolution of the PAA and pulmonary or intracardiac thrombus.

\section{Statistical analysis}

Quantitative data were presented as mean \pm standard deviation with range and median values, and intergroup differences were compared using the unpaired $t$ test. Frequencies were compared using Fisher's exact test. Univariate and multivariate analyses were conducted to evaluate predictive risk factors. Results with $\mathrm{p}<0.05$ were considered statistically significant.

\section{RESULTS}

The literature search yielded 107 reports $^{5}$ 10,13-118 covering 199 patients. Five case reports, each describing the case of one patient, diagnosed Hughes-Stovin syndrome. ${ }^{37,49,51,54,99}$ Among the patients whose gender could be ascertained, there were $166(85.6 \%)$ males and $28(14.4 \%)$ females, giving a male-to-female ratio of 5.93:1. Patients were aged $31.0 \pm 10.9$ (range: 10-69; median: 30)

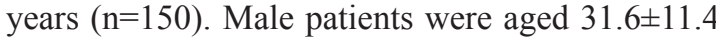
(range: 10-69; median: 30$)(\mathrm{n}=122)$ and females were aged $28.6 \pm 8.5$ (range: 14-48; median: 27 ) $(\mathrm{n}=24)$. There was no significant difference in patient age between male and female patients $(\mathrm{p}=0.2249)$. Patients had presented symptoms of Behçet's disease for 5.0 \pm 4.8 (range: $0.25-26$; median: 3 ) years $(n=52)$ and their diagnoses of Behçet's disease had been established for 4.7 \pm 2.9 (range: 0.83-10; median: 5) years $(n=34)$. No difference was detected between the time since onset and time since Behçet's disease diagnosis $(\mathrm{p}=0.7522)$. On admission, $156(78.4 \%)$ patients presented with hemoptysis, while $43(21.6 \%)$ patients did not exhibit hemoptysis $\left(\chi^{2}=128.3\right.$, $\mathrm{p}<0.0001)$. Hemoptysis was the only symptom at onset in 109 (69.9\%) patients, while hemoptysis was present in combination with other symptoms in $47(30.1 \%)$ patients $\left(\chi^{2}=49.3, p<0.0001\right)$. In 
addition to hemoptysis, fever, dyspnea, cough and chest pain were also common symptoms in the PAA patients. Comparison of the secondary symptoms of hemoptysis patients with those of hemoptysis-free patients revealed a significant intergroup difference in prevalence of cervical or pedal edema (Table 1). Hemoptysis volume was reported for 69 patients. Hemoptysis was mild in $5(7.2 \%)$ patients, ${ }^{28,48,55,65,68}$ moderate in $9(13.0 \%),{ }^{37,50,57,70,71,76,95,112,118}$ (1 patient with increasing hemoptysis volumes $\left.{ }^{76}\right)$, massive in

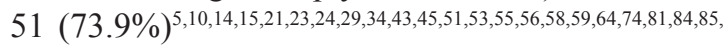
$87,96,98,99,109-111,115$ ( 2 patients with increasing hemoptysis volumes $\left.^{84,85}\right)$ and life-threatening in $4(5.8 \%)$ patients $^{25,34,41,42}\left(\chi^{2}=118.5, p<0.0001\right)$. Frequency of hemoptysis was reported for 17 patients, as follows: recurrent/repeated/iterative in $9(52.9 \%),{ }^{14,21,54,58}$, $59,63,65,72,79$ intermittent in $6(35.3 \%)^{21,27,57,81,113,118}$ and persistent in $2(11.8 \%)$ patients. ${ }^{18,63}$ Additionally, one patient was described as having hemoptysis of unknown origin on admission. ${ }^{47}$ Overall, duration of the PAA patients' symptoms was $2.6 \pm 4.1$ (range: 0.03-24; median: 1.5) months $(\mathrm{n}=35)$. One exceptional patient exhibited clinical manifestations 14 days after admission. ${ }^{26}$

Erythrocyte sedimentation rate was tested for 43 patients. Results were elevated in $39(90.7 \%)$

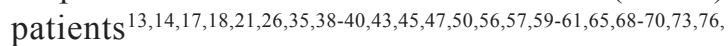
$81,83,88,92,93,95,98,104,106,108,111-113,116,118$ and normal in $4(9.3 \%)$ patients $^{21,35,37,43}\left(\chi^{2}=57.0, \mathrm{p}<0.0001\right)$. The quantitative erythrocyte sedimentation rate for these patients was $72.2 \pm 34.9$ (range: $10-152$; median: 71.5 ) $\mathrm{mm} / \mathrm{h}$ $(\mathrm{n}=38)$. Seventeen patients had C-reactive protein tested and results showed normal C-reactive protein in $1(5.9 \%)$ patient ${ }^{35}$ and elevated C-reactive protein levels in $16(94.1 \%)$ patients, with a quantitative value of $8.7 \pm 5.7$ (range: 1.5-19.7; median: 7.6) $\mathrm{mg} / \mathrm{dl}(\mathrm{n}=15){ }^{13,21,38,39,61,62,66,76,81,92,104,106,107,116,118}$
Pulmonary artery aneurysms developed on the right side in 111 patients $(39.4 \%)$, 5,10,14,16,29,32-34,36-38,56, $60,61,75,76,79,85,86,107,109,112,114-116,118$ on the left side in 91

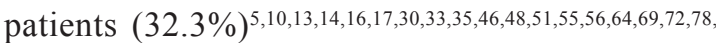
$87,88,94,98,100,102,109,111,118$ and on both sides in 72 patients

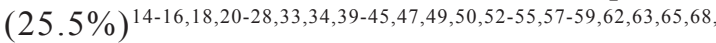
$70,73,74,77,78,80,81,83,84,89-91,93,95-97,100,101,104,105,106,108,109,113,115$ $\left(\chi^{2}=12.5, \mathrm{p}=0.00194\right)$. In 43 patients $(30.1 \%)$ PAAs were single, in 97 (67.8\%) they were multiple, and in 3 patients (2.1\%), PAAs extended from the main pulmonary branch to lobar (segmental) arteries $\left(\chi^{2}=140.1, p<0.0001\right)$. With regard to singularity versus multiplicity, the most common type of PAA were multiple bilateral PAAs (Figure 1). Detailed locations in the pulmonary zones were provided for 381 PAAs in 146 patients described in a total of 82 different reports, $5,10,13-18,20-29,32-35,37-46,48,49,51,52-54,56-62,64$, 65,68-70,72,74-76,78-81,83,87-89,91,93,95,96,98,102,104-107,109-116,118

showing that 293 (76.9\%) PAAs originated from the lobar arteries, $45(11.8 \%)$ from the segmental

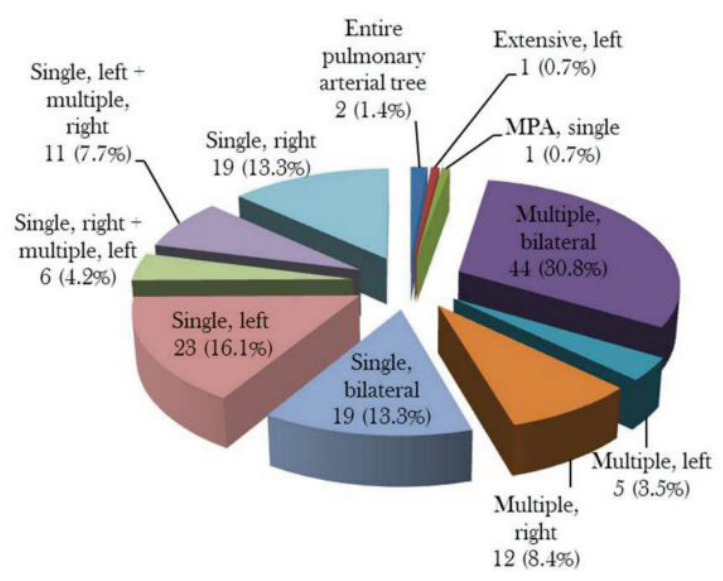

Figure 1. Singularity and multiplicity of pulmonary artery aneurysms. MPA: main pulmonary artery.

Table 1. Comparison of symptoms of 47 hemoptysis patients and 43 patients free from hemoptysis.

\begin{tabular}{|c|c|c|c|c|}
\hline Symptom & Hemoptysis patients $(\mathrm{n}=81)$ & Hemoptysis-free patients $(n=67)$ & $\chi^{2}$ & $\mathrm{p}$ value \\
\hline Fever, n (\%) & $\begin{array}{l}22 \text { (27.2) (1 [4.5] was fever } \\
\text { of unknown origin) }\end{array}$ & $\begin{array}{c}26(38.8)(1[3.8] \text { was fever } \\
\text { of unknown origin })\end{array}$ & 2.3 & 0.13196 \\
\hline Dyspnea, n (\%) & $17(21.0)$ & $13(19.4)$ & 0.1 & 0.81134 \\
\hline Cough, n (\%) & $15(18.5)$ & $15(22.4)$ & 0.3 & 0.55998 \\
\hline Chest pain, n (\%) & $13(16.0)$ & $8(11.9)$ & 0.5 & 0.47579 \\
\hline Weight loss, n (\%) & $9(11.1)$ & $2(3.0)$ & 3.5 & 0.06066 \\
\hline Edema, n (\%) & $\begin{array}{c}3(3.7)(1[33.3] \text { was cervical } \\
\text { and } 2[66.7] \text { were pedal edema })\end{array}$ & $0(0)$ & 3.9 & 0.04855 \\
\hline Loss of vision, $\mathrm{n}(\%)$ & $1(1.2)$ & $0(0)$ & 1.3 & 0.25688 \\
\hline Cardiac arrest, $\mathrm{n}(\%)$ & $1(1.2)$ & $0(0)$ & 1.3 & 0.25688 \\
\hline Palpitation, n (\%) & $0(0)$ & $1(1.5)$ & 1.8 & 0.18407 \\
\hline Epilepsy, n (\%) & $0(0)$ & $1(1.5)$ & 1.8 & 0.18407 \\
\hline Stroke, n $(\%)$ & $0(0)$ & $1(1.5)$ & 1.8 & 0.18407 \\
\hline
\end{tabular}


arteries, $40(10.5 \%)$ from the main pulmonary arteries and $3(0.8 \%)$ extended from the main pulmonary branches to the lobar (segmental) arteries $\left(\chi^{2}=744.6, p<0.0001\right)$. Analysis of the distribution of the PAAs across pulmonary zones revealed that the right lower lobar arteries predominated, followed by the left lower lobar arteries (Figure 2).

The mean dimension of PAAs was $4.0 \pm 2.4$ (range: $0.5-13$; median: 3.6$) \mathrm{cm}(\mathrm{n}=60)$. The PAAs were pseudoaneurysms in $5(2.5 \%)$ patients, ${ }^{72}$, $87,88,91,118$ while all the remaining PAAs were true aneurysms $\left(\chi^{2}=359.0, p<0.0001\right)$. A significant difference in diameter was detected between false and true aneurysms (8.0 \pm 3.5 [range: $4-13$; median: 4] cm vs. $3.7 \pm 2.0$ [range: $0.5-9$; median: 3.1 ] cm, $\mathrm{p}<0.0001)$. Ten patients $(5.0 \%)$ suffered from PAA

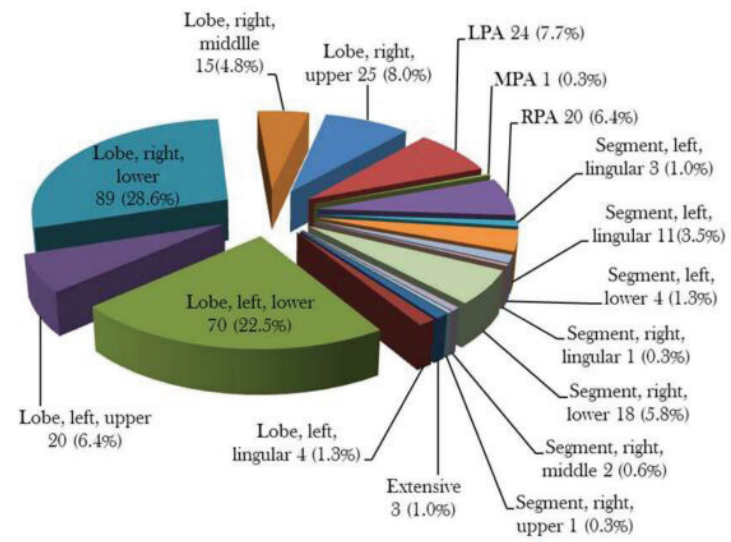

Figure 2. Distribution of pulmonary artery aneurysms. LPA: left pulmonary artery; MPA: main pulmonary artery; RPA: right pulmonary artery.

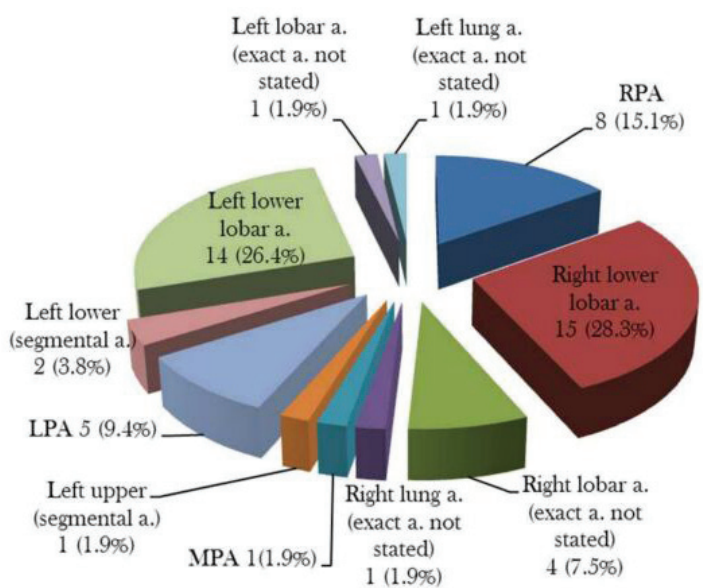

Figure 3. Distribution of concurrent intramural thromboses of pulmonary artery aneurysms. a: artery; LPA: left pulmonary artery; MPA: main pulmonary artery; RPA: right pulmonary artery. rupture..$^{38,55,62,64,75,84,109,115,118}$ In two large PAA patient cohorts, concurrent pulmonary artery thrombus accounted for 15/46 PAAs in 13 patients ${ }^{110}$ and 8/96 PAAs in 43 patients. ${ }^{5,109}$ In another 35 reports, ${ }^{5,10,13}$, $14,16,18,21,23,27,33,34,38,46-49,56,58,60,63,68-70,74,79,81,84,94,108-111,114-116$ concurrent intramural thrombus was present in 53 PAAs in $41(28.7 \%, 41 / 143)$ patients. Thrombi were located in right, left and bilateral PAAs in $18(43.9 \%)$, $12(29.3 \%)$ and $10(24.4 \%)$ patients, respectively, and in a main pulmonary artery aneurysm in $1(2.4 \%)$ patient. Concurrent PAA and intramural thrombosis was most often seen in the right lower lobar and left lower lobar arteries (Figure 3).

Excluding pulmonary arterial thrombus, intrapulmonary complications were present in 10 $(5.0 \%)$ patients, including $5(50 \%)$ pulmonary infarcts, $4(40 \%)$ pulmonary emboli and $1(10 \%)$ pulmonary emboli and infarct. Extrapulmonary cardiovascular events occurred in $56(28.1 \%)$ patients, including thrombus formation in 52 $(92.9 \%)$, and arterial aneurysm and vein dilation in $2(3.6 \%)$ patients, each (Table 2).

Management strategies for the PAAs were not described for 70 patients. Of the remaining 129 patients, $82(63.6 \%)$ were treated conservatively, ${ }^{10,13-15,17-19,22 \text {, }}$ $23,25,27-29,31,37,38,40,41,46,49-56,61-63,65,68-70,73,75,78,81,83,84,86,91,94,95$, 97,99,100,102-104,105,108,112-116,118 $22(17.1 \%)$ were treated interventionally $10,24,32,34,42,47,60,64,71,72,74-76,79,87,89,92,96$ and

Table 2. Extrapulmonary cardiovascular events in 56 patients.

\begin{tabular}{lc}
\hline Extrapulmonary cardiovascular events & $\mathrm{n}(\%)$ \\
\hline Arterial aneurysm & $2(3.6)$ \\
Femoral artery & $1(1.8)$ \\
Coronary artery & $1(1.8)$ \\
Dilated veins & $2(3.6)$ \\
Azygous vein & $1(1.8)$ \\
Hepatic vein & $1(1.8)$ \\
Thrombus formation & $52(92.9)$ \\
RV & $18(32.1)$ \\
DVT & $11(19.6)$ \\
IVC & $4(7.1)$ \\
RA & $3(5.4)$ \\
Dural sinus + DVT & $3(5.4)$ \\
RA + RV & $2(3.6)$ \\
Dural sinus + RV & $2(3.6)$ \\
SVC & $2(3.6)$ \\
Dural sinus & $1(1.8)$ \\
Dural sinus + RV + DVT & $1(1.8)$ \\
IVC + DVT & $1(1.8)$ \\
RV + DVT & $1(1.8)$ \\
RV + SVC & $1(1.8)$ \\
Dural sinus + jugular vein & $1(1.8)$ \\
SVC + innominate vein & $1(1.8)$ \\
\hline
\end{tabular}

DVT: deep venous thrombosis; IVC: inferior vena cava; RA: right atrium; RV: right ventricle; SVC: superior vena cava. 
$25(19.4 \%)$ were treated surgically with concurrent

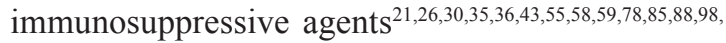
$100,106,107,110,111,115,118\left(\chi^{2}=79.7, p<0.0001\right)$. Two patients given conservative treatment were eventually treated for PAA interventionally because of PAA progression $^{40,41}$ and one patient who originally underwent interventional embolization of the PAA was later subjected to emergency pulmonary artery ligation because of PAA recurrence with severe hemoptysis and respiratory distress. ${ }^{24}$ There were a total of 24 interventional and 26 surgical procedures for PAAs. Additionally, one patient underwent resection of endomyocardial fibrosis plus tricuspid valve repair ${ }^{101}$ and one patient underwent surgical excision of intracardiac mass. ${ }^{56}$

Of the whole patient sample, immunosuppressive treatment strategies were described in 114 patients. Steroids were administered to $101(88.6 \%)$, cyclophosphamide to $62(54.4 \%)$, azathioprine $(150 \mathrm{mg} /$ day or $2 \mathrm{mg} / \mathrm{kg} /$ day) to $25(21.9 \%)$, colchicine (0.5-1.5 mg/day) to $36(31.6 \%)$, anticoagulants to 22 (19.3\%), methotrexate to $3(2.6 \%)$ and cyclosporine A was administered to $2(1.8 \%)$ patients. Alternative conservative treatments included infliximab, a tumor necrosis factor neutralizing agent, $5 \mathrm{mg} /$ $\mathrm{kg}$ at $0,2,6,14$ and 22 weeks in $3(2.6 \%)$ cases, adalimumab, a human monoclonal antibody against tumor necrosis factor- $\alpha$, in $2(1.8 \%)$, hematopoietic stem cell transplantation in $2(1.8 \%)$ and mycophenolate mofetil in 1 case $(0.9 \%)$. Onset of action was soon after drug administration in 5 (4.4\%) patients. ${ }^{22,52,58,104,118}$ In another 31 patients, ${ }^{13}$, $15,17,18,20,25,37,46-48,50,51,61,65,69,81,94,97,103,109,116$ onset of action took 13.6 23.5 (range: 0.25-120; median: 6) months $(\mathrm{n}=44)$. Cure time was $6.4 \pm 5.5$ (range: $2-24$; median: 5) months ( $\mathrm{n}=18) .{ }^{14,25,34,38,46,47,54,56,59,61,63,65,73 \text {, }}$ $81,91,95,113,116$ In 11 cases PAA embolization materials were described, as follows: N-butyl cyanoacrylate $(\mathrm{n}=3,27.3 \%),{ }^{34,41}$ Nester ${ }^{\circledR}$ Embolization Coils $(\mathrm{n}=3$, 27.3\%), ${ }^{74,76}$ Amplatzer devices $(n=3,27.3 \%),{ }^{64,66,72}$ Ethylene Vinyl Alcohol Copolymer $(\mathrm{n}=1,9.1 \%)^{71}$ and Guglielmi detachable coils $(\mathrm{n}=1,9.1 \%) \cdot{ }^{60}$ In patients with multiple PAAs, the number of embolization coils deployed in a single patient varied from $2,{ }^{74}$ through $6,{ }^{74}$ to $10 .{ }^{76}$ Details of surgical operations performed on PAA patients are listed in Table 3, showing that lobectomy was the most common surgical operation, accounting for $42.3 \%$ of surgical procedures.

The indications for conservative treatment in severe patients were extensive PAA locations, ${ }^{55,97}$ failed interventional embolization ${ }^{95}$ and patient reluctance to undergo interventional embolization or surgical operations. ${ }^{29,68,114}$ Hematopoietic stem cell transplantation ${ }^{86}$ and tumor necrosis factor- $\alpha$ plus infliximab ${ }^{25}$ were indicated for patients refractory to conventional immunosuppressive therapy. Indications for interventional embolization included bilateral pulmonary artery involvement, ${ }^{74}$ giant pulmonary artery pseudoaneurysm, ${ }^{87}$ ruptured PAAs,${ }^{64}$ failed conservative treatment, ${ }^{34}$ to avoid potential surgical complications ${ }^{60}$ and patients' reluctance to undergo surgical operations. ${ }^{72}$ Patients with rapidly expanding pulmonary artery (pseudo)aneurysms ${ }^{24,26,107}$ or with recurrent PAA following successful percutaneous embolization ${ }^{24}$ usually warranted surgical operations; while patients with uncontrolled massive hemoptysis with impending PAA rupture often required an emergency operation. ${ }^{55,59,106,110}$ A total of 9 patients received intervention/surgery for the treatment of PAA on an urgent basis including 1 interventional embolization $^{41}$ and 8 open thoracic operations. ${ }^{24,35,55}$, ${ }_{85,110,115,118}$ In all 9 of these patients an urgent procedure was indicated for massive hemoptysis, and 4 (44.4\%) patients of whom suffered from a PAA rupture. ${ }^{55,110,}$ ${ }^{115,118}$ Patients were followed-up for 22.5 \pm 33.5 (range:

Table 3. Surgical operations for pulmonary artery aneurysms in 26 patients.

\begin{tabular}{lc}
\hline \multicolumn{1}{c}{ Surgical operation } & $\mathrm{n}(\%)$ \\
\hline Lobectomy & $11(42.3)$ \\
Pneumonectomy & $3(11.5)$ \\
PAA excision & $2(7.7)$ \\
Pulmonary artery ligation & $2(7.7)$ \\
Pulmonary artery aneurysmorrhaphy & $1(3.8)$ \\
Pulmonary artery aneurysmorrhaphy + pneumonectomy & $1(3.8)$ \\
Pulmonary artery aneurysmectomy + pneumonectomy & $1(3.8)$ \\
Thoracotomy (patient died during thoracotomy with no time for further interventions) & $1(3.8)$ \\
Lobectomy + pulmonary arterioplasty & $1(3.8)$ \\
Left pulmonary artery replacement under cardiopulmonary bypass & $1(3.8)$ \\
Left and right pulmonary artery operations (details not stated) & $1(3.8)$ \\
Surgical operation (details not stated) & $1(3.8)$ \\
\hline
\end{tabular}


0.75-204; median: 15) months ( $\mathrm{n}=94)$. Outcomes were not described for 24 patients. Of the remaining 175 patients, $108(61.7 \%)$ were event-free survivals and $44(25.1 \%)$ patients died. Time to death was reported for 30 patients, 11 (36.7\%) of whom were early deaths and $19(63.3 \%)$ of whom were late deaths $\left(\chi^{2}=4.3, \mathrm{p}=0.03887\right)$. Mean time to death was $6.1 \pm 7.2$ (range: $0-24$; median: 3 ) months after intervention or after discharge (a " 0 " indicates that one patient died of uncontrolled massive bleeding during the operation $\left.{ }^{83}\right)$. Cause of death was described for 27 patients: massive hemoptysis in 20 (74.1\%), PAA rupture in 4 (14.8\%), pulmonary hemorrhage as evidenced by bronchoscopy in $2(7.4 \%)$, postoperative bleeding in $1(3.7 \%)$ patient and septicemia in 1 patient $(3.7 \%)\left(\chi^{2}=47.2, p<0.0001\right)$.

Outcomes were reported for 175 patients and comparison of outcomes across different treatments revealed that conservatively treated patients were prone to suffer from PAA progression, that interventional embolization was associated with higher risks of recurrence and reintervention for PAAs, and that surgically treated patients had the highest overall and early mortality rates. However, there were no significant differences in late mortality between these three groups (Table 4). The time to death of surgically treated patients was much shorter than among conservatively treated patients $(2.3 \pm 5.9$ months vs. $7.8 \pm 6.4$ months, $\mathrm{p}=0.04650$ ). There were 24 interventional procedures, $23(95.8 \%)$ of which were elective including $1(4.3 \%)$ postoperative death, while $1(4.2 \%)$ was an emergency intervention and the patient survived. There were 26 surgical procedures, $21(80.8 \%)$ of which were elective, including $9(42.9 \%)$ deaths; whereas 5 (19.2\%) were emergency surgeries, including $3(60 \%)$ deaths $\left(\chi^{2}=0.5, p=0.48953\right)$. Ten patients suffered PAA rupture. Four of them had been managed conservatively, 4 had been managed surgically and 2 had been managed interventionally, with only 2 surgically-treated patients surviving, giving an overall survival rate of $20 \%$ and an emergency surgery survival rate of $50 \%\left(\chi^{2}=5.0, p=0.08416\right)$.

Univariate analysis revealed that presence of hemoptysis $(\mathrm{p}<0.0001)$, lobar artery involvement $(\mathrm{p}=0.00200)$ and PAA rupture $(\mathrm{p}=0.00900)$ were statistically significant adverse prognostic factors indicative of poor prognosis in PAA patients, whereas intramural pulmonary artery thrombus $(\mathrm{p}=0.16000)$, surgical intervention $(p=0.20900)$, emergency operation $(p=0.23100)$ and PAA multiplicity $(p=0.97400)$ were not predictive. Attempts to identify independent risk factors for mortality using multiple logistic regression employed hemoptysis, lobar arterial aneurysm, multiplicity, concurrent intramural thrombus and surgical/interventional therapy as input variables, overall model fit parameters were: $\chi^{2}=14.1580, \mathrm{df}=5, \mathrm{p}=0.0146$. Mortality correlated significantly with lobar artery involvement, and there was a quasi-correlation with hemoptysis (Table 5).

\section{DISCUSSION}

The pulmonary vasculitis seen in PAA associated with Behçet's disease is primarily located in the vasa vasorum. Histopathological observations revealed pulmonary vasculitis involving all layers of pulmonary arteries and veins, ${ }^{3}$ resulting in thrombosis, stenosis, aneurysm formation and rupture. Mononuclear inflammatory cells, predominantly lymphocytes, are responsible for inflammatory infiltration in and around the vessel wall. Additionally, impaired natural killer cell activity and immune system dysregulation have also been observed in patients with Behçet's disease and pulmonary manifestations. ${ }^{119}$ Marked intimal thickening with degenerative changes in the

Table 4. A comparison of the outcomes of 173 patients with pulmonary artery aneurysm: patients treated conservatively versus surgically versus interventionally.

\begin{tabular}{|c|c|c|c|c|c|c|}
\hline Outcome & $\begin{array}{c}\text { Conservative } \\
(n=83)\end{array}$ & Surgical $(n=25)$ & $\begin{array}{l}\text { Interventional } \\
\quad(n=24)\end{array}$ & $\begin{array}{c}\text { Treatment not } \\
\text { indicated }(n=66)\end{array}$ & $\chi^{2}$ & $\mathrm{p}$ value \\
\hline Event-free survival, n (\%) & $47(56.6)$ & $10(40)$ & $12(50)$ & $39(59.1)$ & 9.3 & 0.00970 \\
\hline Progression, n (\%) & $7(8.4)^{* *}$ & $0(0)$ & $0(0)$ & $1(1.5)$ & 6.7 & 0.03473 \\
\hline Recurrence, n (\%) & $4(4.8)$ & $1(4)$ & $5(20.8)+$ & $4(6.1)$ & 8.4 & 0.01464 \\
\hline Complication, n (\%) & $2(2.4) \neq$ & $1(4)$ & $2(8.3)+$ & $0(0)$ & 2.1 & 0.34975 \\
\hline Reintervention, n (\%) & $0(0)$ & $0(0)$ & $7(29.2)$ & $0(0)$ & 42.1 & $<0.00001$ \\
\hline Outcome not stated, n (\%) & $6(7.2)$ & $1(4)$ & $2(8.3)$ & $14(21.2)$ & -- & -- \\
\hline Death, n (\%) & $20(24.1)$ & $12(48)$ & $3(12.5)$ & $8(12.1)$ & 8.0 & 0.01872 \\
\hline Early death & $2(10)$ & $5(41.7)$ & $1(33.3)$ & $1(12.5)$ & 10.4 & 0.00548 \\
\hline Late death & $18(90)$ & $7(58.3)$ & $2(66.7)$ & $7(87.5)$ & 2.7 & 0.26446 \\
\hline
\end{tabular}

* One patient died due to the refusal of all treatments and was not therefore a member of any of the above groups; ${ }^{* *}$ Two patients eventually died; $\uparrow$ Reintervention was required in all patients; $\neq$ One patient died. 
Table 5. Odds ratios and $95 \%$ confidence intervals for multivariate regression analysis of risk factors predictive of mortality.

\begin{tabular}{lccc}
\hline \multicolumn{1}{c}{ Variable } & Odds ratio & 95\% confidence interval & $\mathrm{p}$ value \\
\hline Hemoptysis & 2.6030 & $0.9573-7.0779$ & 0.0609 \\
Lobar arterial involvement & 0.3025 & $0.1062-0.8614$ & 0.0251 \\
Multiplicity of the pulmonary artery aneurysm & 1.4231 & $0.6332-3.1986$ & 0.3931 \\
Concurrent pulmonary artery aneurysm and & 0.7596 & $0.2986-1.9323$ & 0.5638 \\
intramural thrombus & & & $0.7041-3.6408$ \\
Surgical/interventional therapy & 1.6011 & 0.2614 \\
\hline
\end{tabular}

medial layer from the lobar branches to the arterioles can explain hemoptyisis and PAA rupture. ${ }^{120}$ Bronchopulmonary fistulas found during autopsies of patients who died of sudden hemoptysis ${ }^{43}$ and in surgical specimens resected from patients with massive hemoptysis ${ }^{10,110}$ were apparently the causative etiology of life-threatening hemoptysis.

Aneurysms may be single or multiple, unilateral or bilateral, saccular or fusiform, and may be located in the main pulmonary artery or lobar or segmental arteries. ${ }^{2}$ Pulmonary vasculitis in Behçet's disease may also result in thrombosis, stenosis or occlusion of lung vessels, but thrombosis rather than embolism was usually associated with PAAs. ${ }^{121}$ Other pulmonary problems seen in Behçet's disease patients, including pleural effusion and chylous pleural effusions, are the result of vascular complications. ${ }^{11}$ Focal hemorrhages or infarct areas can present in the lung parenchyma adjacent to the aneurysms. ${ }^{120}$ Thrombosed aneurysms cause ischemia and infarction in the pulmonary parenchyma. ${ }^{6}$ Pulmonary artery aneurysms may manifest as hilar enlargement or round, lobulated opacities on chest radiographs. ${ }^{16}$ Computed tomography has largely replaced angiography as the diagnostic tool and magnetic resonance imaging can also be useful for diagnosis of PAAs, but appears to be less sensitive than computed tomography for diagnosis of small PAAs. ${ }^{2}$

Erkan et al. ${ }^{2}$ reported that PAAs are most often located in the right lower lobar arteries, followed by bilateral main pulmonary branches. Tunaci et al. ${ }^{109}$ proposed that the pulmonary arteries of the lower lobe were the most common site of involvement, and a mural thrombus was observed in $85 \%$ of PAAs. Aneurysms were most frequently located in the lobar artery in the right lower lobe (35\%), followed by the lobar artery in the left lower lobe (19\%) and right main pulmonary artery $(17 \%)$, and $33 \%$ of aneurysms had partial or total thrombus within the aneurysm itself. ${ }^{109}$ The present study showed similar results to those published by Tunaci et al. ${ }^{109}$ Another important finding of Tunaci et al. ${ }^{109}$ was complete or partial
PAA resolution in response to immunosuppressive treatments: $76 \%$ of PAAs completely disappeared in 3-42 (mean: 21 ) months and $24 \%$ of PAAs regressed in 4-28 (mean: 17) months after treatment. ${ }^{109}$ It was reported that the largest aneurysm was $7 \mathrm{~cm},{ }^{109}$ and the mean diameter of aneurysms was $2.3 \pm 1.1 \mathrm{~cm} .{ }^{122}$ The present study, however, revealed much larger dimensions of PAAs with a mean diameter of $4.0 \mathrm{~cm}$.

In Behçet's disease, immunosuppressants should be the first line treatment of choice and provoke regression of the PAAs and associated thrombus in a majority of the patients. ${ }^{21}$ Pulse methylprednisolone followed by oral prednisolone is one routine regimen for Behçet's disease. ${ }^{48,50,59}$ Monthly intravenous cyclophosphamide $1 \mathrm{~g}$, and azathioprine $2.5 \mathrm{mg} / \mathrm{kg}$ /day may also be employed. ${ }^{88}$ Tumor necrosis factor-neutralizing monoclonal antibody infliximab was an effective treatment for a case of potentially lethal PAA in Behçet's disease. ${ }^{25}$ Two patients with resistant PAA were treated with hematopoietic stem cell transplantation. ${ }^{86}$ Other tumor necrosis factor- $\alpha$ blockers, which include etanercept and adalimumab, would also be effective for the treatment of PAA in Behçet's disease patients. ${ }^{77}$ Pulmonary artery aneurysm patients with thrombophlebitis and/or pulmonary emboli who are on anticoagulants are at risk of massive bleeding and so anticoagulants should be used with great caution, especially in patients with hemoptysis. ${ }^{76}$

Alternative management strategies to conservative treatment include surgical and transcatheter interventions. Diseased lung tissue resection is preferred to pulmonary artery reconstruction in surgical treatment of PAAs. Surgical treatment mostly consists of major anatomical resection rather than preserving lung tissue. Immediate operation for PAAs should be performed when systemic inflammation is under control after short-term immunosuppressive therapy. ${ }^{21}$ Patients with recurrent or massive hemoptysis, in particular patients with ruptured PAAs, warrant emergency surgery, which is often associated with very high mortality. ${ }^{21}$ Endovascular embolization has been shown to be 
effective at controlling PAA hemorrhage. ${ }^{34}$ The Amplatzer duct occluder is currently the most commonly used device for management of large aneurysms. ${ }^{88}$ It can be employed in most cases and recurrent PAAs may be curable with reintervention. ${ }^{32}$

Pulmonary artery aneurysms were the major contributing factor to overall mortality from Behçet's disease. ${ }^{121}$ In the early years, short-term survival of patients with PAAs associated with Behçet's disease was only $50 \% .^{3}$ A decade later, 5-year survival had increased to $62 \% .{ }^{4}$ The present study displayed an overall survival of $76.9 \%$ at a mean follow-up of 21.6 months.

The present study revealed that PAAs have predilections for hemoptysis manifestations, right lower lobar locations, multiplicity and concurrent intramural thrombus formation. Surgical intervention therapy is warranted in most of the patients. All these variables were shown to be predictive risk factors for higher mortality in PAAs. For refractory cases that respond poorly to conservative treatment, endovascular embolization and Amplatzer occluder device are good choices for PAA management. Hemorrhaging PAAs can also be controlled by pneumonectomy, lobectomy, pulmonary artery aneurysmectomy, or pulmonary arterial ligation, but these options may be associated with higher mortality compared with interventionally and conservatively treated patients.

The most important limitations of this review are related to the non-availability of numbers, locations and dimensions of the arteries involved by PAAs in a large proportion of the references cited. Further prospective studies with more detailed information of PAAs are essential if more precise conclusions are to be drawn.

In conclusion, PAAs in Behçet's disease are characterized by a predilection for hemoptysis manifestations, right lower lobar location, multiplicity and concurrent intramural thrombus formation. Both the condition itself and the surgical operations it warrants are linked with high mortality due to PAA hemorrhage.

\section{REFERENCES}

1. Seyahi E, Yurdakul S. Behçet's syndrome and thrombosis. Mediterr J Hematol Infect Dis. 2011;3(1):e2011026. http://dx.doi. org/10.4084/MJHID.2011.026. PMid:21869912

2. Erkan F, Gül A, Tasali E. Pulmonary manifestations of Behçet's disease. Thorax. 2001;56(7):572-8. http://dx.doi.org/10.1136/ thorax.56.7.572. PMid:11413359

3. Hamuryudan V, Yurdakul S, Moral F, et al. Pulmonary arterial aneurysms in Behçet's syndrome: a report of 24 cases. $\mathrm{Br}$
J Rheumatol. 1994;33(1):48-51. http://dx.doi.org/10.1093/ rheumatology/33.1.48. PMid:8162457

4. Hamuryudan V, Er T, Seyahi E, et al. Pulmonary artery aneurysms in Behçet syndrome. Am J Med. 2004;117(11):867-70. http:// dx.doi.org/10.1016/j.amjmed.2004.05.027. PMid:15589493

5. Seyahi E, Melikoglu M, Akman C, et al. Pulmonary artery involvement and associated lung disease in Behçet disease: a series of 47 patients. Medicine (Baltimore). 2012;91(1):35-48 http://dx.doi.org/10.1097/MD.0b013e318242ff37. PMid:22210555

6. Erkan F, Kiyan E, Tunaci A. Pulmonary complications of Behçet's disease. Clin Chest Med. 2002;23(2):493-503. http://dx.doi. org/10.1016/S0272-5231(01)00014-4. PMid:12092042

7. Saadoun D, Wechsler B. Hughes-Stovin syndrome. Orphanet The Portal of Rare Diseases and Orphan Drugs. 2011 Dec [cited 2013 July 04]. http://www.orpha.net/consor/cgi-bin/OC_Exp. php?lng=en\&Expert $=228116$

8. Khalid U, Saleem T. Hughes-Stovin syndrome. Orphanet J Rare Dis. 2011;6(1):15. http://dx.doi.org/10.1186/1750-1172-6-15. PMid:21489283

9. Uzun O. Pulmonary involvement in Behçet's disease and Takayasu's arteritis. Eur Respir Mon. 2011;54:32-45.

10. Uzun O, Erkan L, Akpolat I, Findik S, Atici AG, Akpolat T. Pulmonary involvement in Behçet's disease. Respiration. 2008;75(3):310-21. http://dx.doi.org/10.1159/000101954 PMid:17446699

11. Uzun O, Akpolat T, Erkan L. Pulmonary vasculitis in behcet disease: a cumulative analysis. Chest. 2005;127(6):2243-53. http:// dx.doi.org/10.1378/chest.127.6.2243. PMid:15947344

12. Hemoptysis. [cited 2013 July 04]. http://thelungcenter.co.in/ yahoo_site_admin/assets/docs/hemoptysis.107184533.pdf

13. Aamar S, Peleg H, Leibowitz D, Chajek-Shaul T, Hiller N, Heyman SN. Efficacy of adalimumab therapy for life-threatening pulmonary vasculitis in Behçet's disease. Rheumatol Int. 2014;34(6):857-60. PMid:23412691

14. Acican T, Gürkan OU. Azathiopine-steroid combination therapy for pulmonary arterial aneurysms in Behçet's disease. Rheumatol Int. 2001;20(4):171-4. http://dx.doi.org/10.1007/s002960100102. PMid:11411965

15. Agha A, Bella AM, Assiri AH, Al-Hakami M. Can Behcet's disease related pulmonary arterial aneurysms be completely resolved? Open Rheumatol J. 2011;5(1):88-90. http://dx.doi.org/10.2174/1 874312901105010088. PMid:22216070

16. Ahn JM, Im JG, Ryoo JW, et al. Thoracic manifestations of Behçet syndrome: radiographic and CT findings in nine patients. Radiology. 1995;194(1):199-203. PMid:7997553.

17. Aksu K, Koçanaoğullari H, Keser G, et al. A case of Behçet's disease with pulmonary arterial aneurysm and secondary amyloidosis. Rheumatology (Oxford). 2002;41(7):831-2. http:// dx.doi.org/10.1093/rheumatology/41.7.831-a. PMid:12096241

18. Aktoğu S, Erer OF, Urpek G, Soy O, Tibet G. Multiple pulmonary arterial aneurysms in Behçet's disease: clinical and radiologic remission after cyclophosphamide and corticosteroid therapy. Respiration. 2002;69(2):178-81. http:// dx.doi.org/10.1159/000056324. PMid:11961435

19. Alkaabi JK, Pathare A. Pattern and outcome of vascular involvement of Omani patients with Behcet's disease. Rheumato Int. 2011;31(6):731-5. http://dx.doi.org/10.1007/s00296-0101363-z. PMid:20130881

20. Alkhatib Y, Al-Aqtash T, Kawar Y, Betensley A. The pulmonary artery giants Of Behcet's disease treated medically. C62. Case Reports: Pulmonary Circulation. 2013:A4604. http://dx.doi. 
org/10.1164/ajrccm-conference.2013.187.1_MeetingAbstracts. A4604.

21. Aroussi AA, Redai M, El Ouardi F, Mehadji BE. Bilateral pulmonary artery aneurysm in Behçet syndrome: report of two operative cases. J Thorac Cardiovasc Surg. 2005;129(5):1170-1. http://dx.doi. org/10.1016/j.jtcvs.2004.08.038. PMid:15867796

22. Aşker S, Aşker M, Gürsu O, Mercan R, Timuçin OB. A Behcet's disease patient with right ventricular thrombus, pulmonary artery aneurysms, and deep vein thrombosis complicating recurrent pulmonary thromboembolism. Case Rep Pulmonol. 2013;2013. http://dx.doi.org/10.1155/2013/492321

23. Atalay F, Ernam D, Okten F, Akar N. Elevated FVIII and FIX level in a Behçet's disease patient with intracardiac thrombosis and pulmonary arterial aneurysms. Thromb Res. 2005;115(12):159-61. http://dx.doi.org/10.1016/j.thromres.2004.08.010. PMid:15567468

24. Attia R, Reidy J, D'Cruz D, Lang-Lazdunski L. Pulmonary artery ligation with lung preservation in Behcet disease: report of a case with prolonged survival. J Thorac Cardiovasc Surg. 2010;139(4):e93-5. http://dx.doi.org/10.1016/j.jtcvs.2009.07.033. PMid:19744671

25. Baki K, Villiger PM, Jenni D, Meyer T, Beer JH. Behcet's disease with life-threatening haemoptoe and pulmonary aneurysms: complete remission after infliximab treatment. Ann Rheum Dis. 2006;65(11):1531-2. http://dx.doi.org/10.1136/ard.2005.045195. PMid:17038456

26. Başak M, Gül S, Yazgan Y, et al. A case of rapidly progressive pulmonary aneurysm as a rare complication of Behçet's syndrome-a case report. Angiology. 1998;49(5):403-8. http:// dx.doi.org/10.1177/000331979804900510. PMid:9591533

27. Basoglu T, Canbaz F, Bernay I, Danaci M. Bilateral pulmonary artery aneurysms in a patient with Behcet syndrome: evaluation with radionuclide angiography and V/Q lung scanning. Clin Nucl Med. 1998;23(11):735-8. http://dx.doi.org/10.1097/00003072199811000-00002. PMid:9814558

28. Bastos AL, de Brito ILA. Pulmonary artery aneurysms in Behçet's disease: case report. Radiol Bras. 2011;44(6):396-8. http://dx.doi. org/10.1590/S0100-39842011000600012.

29. Berkan O, Oztürkcan S, Doğan K, Onen A, Başel H, Hatipoğu A. Pulmonary arterial aneurysm in Behçet's disease. J Eur Acad Dermatol Venereol. 1999;13(2):140-1. http://dx.doi. org/10.1111/j.1468-3083.1999.tb00869.x. PMid:10568496

30. Berkmen T. MR angiography of aneurysms in Behçet disease: a report of four cases. J Comput Assist Tomogr. 1998;22(2):2026. http://dx.doi.org/10.1097/00004728-199803000-00007. PMid:9530379

31. Bilginer Y, Besbas N, Aktay Ayvaz N, Bakkaloglu A, Ozen S. Behcet disease: treatment of vascular involvement in children. Pediatr Rheumatol. 2008;6(Suppl 1):P262. http://dx.doi. org/10.1186/1546-0096-6-S1-P262.

32. Bozkurt AK. Embolisation in Behçet's disease. Thorax. 2002;57(5):469-70. http://dx.doi.org/10.1136/thorax.57.5.469-a. PMid:11978931

33. Caglar M, Ergun E, Emri S. 99Tcm-MAA lung scintigraphy in patients with Behçet's disease: its value and correlation with clinical course and other diagnostic modalities. Nucl Med Commun. 2000;21(2):171-9. http://dx.doi.org/10.1097/00006231200002000-00009. PMid:10758613

34. Cantasdemir M, Kantarci F, Mihmanli I, et al. Emergency endovascular management of pulmonary artery aneurysms in Behçet's disease: report of two cases and a review of the literature. Cardiovasc Intervent Radiol. 2002;25(6):533-7. http:// dx.doi.org/10.1007/s00270-002-1967-0. PMid:12042999

35. Cebi N, Johannes F, Botsios S, Walterbusch G. Intraparenchymal replacement of the left pulmonary artery with implantation of segmental arteries in a 26-year-old patient. J Thorac Cardiovasc Surg. 2003;126(6):2074-7. http://dx.doi.org/10.1016/S00225223(03)00932-2. PMid:14688729

36. Ceyran H, Akçali Y, Kahraman C. Surgical treatment of vasculoBehçet's disease. A review of patients with concomitant multiple aneurysms and venous lesions. Vasa. 2003;32(3):149-53. http:// dx.doi.org/10.1024/0301-1526.32.3.149. PMid:14524035

37. Chalazonitis AN, Lachanis SB, Mitseas P, et al. Hughes-Stovin syndrome: a case report and review of the literature. Cases J. 2009;2(1):98. http://dx.doi.org/10.1186/1757-1626-2-98. PMid:19178695

38. Chang JE, Lee YH, Lee J. Multiple cardiovascular complications in a patient with Behcet's disease. Korean J Intern Med. 2008;23(2):100-2. http://dx.doi.org/10.3904/kjim.2008.23.2.100. PMid:18646513

39. Cho SB, Yun M, Lee JH, Kim J, Shim WH, Bang D. Detection of cardiovascular system involvement in Behçet's disease using fluorodeoxyglucose positron emission tomography. Semin Arthritis Rheum. 2011;40(5):461-6. http://dx.doi.org/10.1016/j. semarthrit.2010.05.006. PMid:20822800.

40. Cil BE, Geyik S, Akmangit I, Cekirge S, Besbas N, Balkanci F. Embolization of a giant pulmonary artery aneurysm from Behcet disease with use of cyanoacrylate and the "bubble technique".J Vasc Interv Radiol. 2005;16(11):1545-9. http://dx.doi. org/10.1097/01.RVI.0000171692.61294.91. PMid:16319165

41. Cil BE, Turkbey B, Canyiğit M, Kumbasar OO, Celik G, Demirkazik FB. Transformation of a ruptured giant pulmonary artery aneurysm into an air cavity after transcatheter embolization in a Behçet's patient. Cardiovasc Intervent Radiol. 2006;29(1):151-4. http://dx.doi.org/10.1007/s00270-005-0225-7. PMid:16328688

42. Cohle SD, Colby T. Fatal hemoptysis from Behcet's disease in a child. Cardiovasc Pathol. 2002;11(5):296-9. http://dx.doi. org/10.1016/S1054-8807(02)00117-5. PMid:12361841

43. de Montpréville VT, Macchiarini P, Dartevelle PG, Dulmet EM. Large bilateral pulmonary artery aneurysms in Behçet's disease: rupture of the contralateral lesion after aneurysmorrhaphy. Respiration. 1996;63(1):49-51. http://dx.doi. org/10.1159/000196515. PMid:8833993

44. Denecke T, Staeck O, Amthauer H, Hänninen EL. PET/ CT visualises inflammatory activity of pulmonary artery aneurysms in Behçet disease. Eur J Nucl Med Mol Imaging. 2007;34(6):970. http://dx.doi.org/10.1007/s00259-007-0429-y. PMid:17447060.

45. Dikensoy O, Bayram NG, Filiz A. Massive haemoptysis in a young woman. Postgrad Med J. 2002;78(917):183, 187-8. http://dx.doi. org/10.1136/pmj.78.917.183-a. PMid:11884709

46. Düzgün N, Anil C, Ozer F, Acican T. The disappearance of pulmonary artery aneurysms and intracardiac thrombus with immunosupressive treatment in a patient with Behçet's disease. Clin Exp Rheumatol. 2002;20(4, Suppl 26):S56-7. PMid:12371638.

47. El Houari T, Oukerraj L, Ghzaiel L, et al. Management of Behçet disease with multiple complications. Hellenic J Cardiol. 2009;50(5):420-2. PMid:19767285.

48. Elqatni M, Sekkach Y, Abouzahir A, Ghafir D. Right atrium thrombus and pulmonary artery aneurysm in a man with Behçet's disease. Intern Med. 2011;50(3):263-4. http://dx.doi. org/10.2169/internalmedicine.50.4590. PMid:21297333 
49. Emad Y, Ragab Y, Shawki A-H, Gheita T, El-Marakbi A, Salama MH. Hughes-Stovin syndrome: is it incomplete Behçet's? Report of two cases and review of the literature. Clin Rheumatol. 2007;26(11):1993-6. http://dx.doi.org/10.1007/s10067-0070609-y. PMid:17457658

50. Endo LM, Rowe SM, Romp RL, Buckmaster MA, Atkinson TP. Pulmonary aneurysms and intracardiac thrombi due to Behçet's disease in an African-American adolescent with oculocutaneous albinism. Clin Rheumatol. 2007;26(9):1537-9. http://dx.doi. org/10.1007/s10067-006-0426-8. PMid:17047893

51. Erkan D, Yazici Y, Sanders A, Trost D, Yazici H. Is Hughes-Stovin syndrome Behçet's disease? Clin Exp Rheumatol. 2004;22(4, Suppl 34):S64-8. PMid:15515789.

52. Ernam D, Atalay F, Alp A, Hasanoğlu HC. A Behçet's disease patient with intracardiac thrombus, pulmonary artery aneurysms complicating recurrent pulmonary thromboembolism. Tuberk Toraks. 2006;54(2):168-71. PMid:16924574.

53. Filiz A, Dikensoy O. Lethal aneurysm formation of pulmonary arteries in a woman with Behçet's disease. Rheumatology (Oxford). 2000;39(2):222-4. http://dx.doi.org/10.1093/ rheumatology/39.2.222A. PMid:10725085

54. Fischer A, Korman DS, West SG. Radiologic vignette: HughesStovin syndrome. Arthritis Rheum. 2005;53(1):114-6. http:// dx.doi.org/10.1002/art.20907. PMid:15696563

55. Gebitekin C, Yilmaz M, Senkaya I, Saba D, Sağdiç K, Ozer G. Fatal haemoptysis due to pulmonary artery aneurysm in Behçet's disease. Eur J Vasc Endovasc Surg. 1997;13(2):233-6. http://dx.doi. org/10.1016/S1078-5884(97)80027-5. PMid:9091163

56. Gönlügür $U$, Atalar $M H$, Kaptanoğlu $M$, et al. Intracardiac thrombus and co-existing pulmonary artery aneurysm in Behçet's disease: two case reports. Turk Respir J. 2003;4(3):153-5.

57. Gopathi S, Hurt RT, Guardiola J. Intracardiac thrombus in Behcet's disease: a rare case in the United States. Respir Med CME. 2011;4(4):154-6. http://dx.doi.org/10.1016/j.rmedc.2011.07.001.

58. Greene RM, Saleh A, Taylor AK, et al. Non-invasive assessment of bleeding pulmonary artery aneurysms due to Behçet disease. Eur Radiol. 1998;8(3):359-63. http://dx.doi.org/10.1007/ s003300050394. PMid:9510565

59. Gül A, Yilmazbayhan D, Büyükbabani N, et al. Organizing pneumonia associated with pulmonary artery aneurysms in Behçet's disease. Rheumatology (Oxford). 1999;38(12):12859. http://dx.doi.org/10.1093/rheumatology/38.12.1285. PMid:10587562

60. Hammad AM, Al-Qahtani SM, Al-Zahrani MA. Huge pulmonary artery aneurysm. Can Respir J. 2009;16(3):93-5. PMid:19557216.

61. Hammami S, Mahjoub S, Ben-Hamda K, Brahem R, Gamra H, Ben Farhat M. Intracardiac thrombus in Behçet's disease: two case reports. Thromb J. 2005;3(1):9. http://dx.doi.org/10.1186/14779560-3-9. PMid: 16042810

62. Hirohata S, Kikuchi H. Histopathology of the ruptured pulmonary artery aneurysm in a patient with Behçet's disease. Clin Exp Rheumatol. 2009;27(2, Suppl 53):S91-5. PMid:19796542.

63. Houman M, Ksontini I, Ben Ghorbel I, et al. Association of right heart thrombosis, endomyocardial fibrosis, and pulmonary artery aneurysm in Behçet's disease. Eur J Intern Med. 2002;13(7):455-7. http://dx.doi.org/10.1016/S09536205(02)00134-6. PMid:12384136

64. Ianniello A, Carrafiello G, Nicotera P, Vaghi A, Cazzulani A. Endovascular treatment of a ruptured pulmonary artery aneurysm in a patient with Behçet's disease using the Amplatzer Vascular Plug 4. Korean J Radiol. 2013;14(2):283-6. http://dx.doi. org/10.3348/kjr.2013.14.2.283. PMid:23482415
65. Ilvan A, Okutan O, Kartaloglu Z, et al. A case of Behcet's disease with pulmonary artery aneurysm and thrombosis. Int I Angiol. 2002;11(2):92-4. http://dx.doi.org/10.1007/BF01616373.

66. Jayachandran NV, Rajasekhar L, Chandrasekhara PK Kanchinadham S, Narsimulu G. Multiple peripheral arterial and aortic aneurysms in Behcet's syndrome: a case report. Clin Rheumatol. 2008;27(2):265-7. http://dx.doi.org/10.1007/s10067007-0713-z. PMid:17929077

67. Kaçar Güveli T, Tamam M, Ergür S, Özülker T, Mülazimoğlu $M$, Özpaçaci T. Behcet's disease with complete obstruction of right pulmonary artery by a thrombus. Turk J Nucl Med. 2009;18(2):53-4.

68. Kanchinadham S, Potikuri D. Multiple pulmonary arterial aneurysms in a young male patient with incomplete Behçet's syndrome. Lung India. 2013;30(1):76-7. http://dx.doi. org/10.4103/0970-2113.106121. PMid:23661925

69. Kasikcioglu E, Akhan H, Cuhadaroglu C, Erkan F. Pulmonary artery aneurysm in Behcet's disease: a case report. Heart Vessels. 2004;19(3):157-9. http://dx.doi.org/10.1007/s00380-003-0742-8. PMid:15168067

70. Kaya A, Ertan C, Gürkan OU, et al. Behçet's disease with right ventricle thrombus and bilateral pulmonary artery aneurysms-a case report. Angiology. 2004;55(5):573-5. http:// dx.doi.org/10.1177/000331970405500516. PMid:15378123

71. Khalil A, Parrot A, Fartoukh M, Djibre M, Tassart M, Carette MF. Pulmonary artery occlusion with ethylene vinyl alcohol copolymer in patients with hemoptysis: initial experience in 12 cases. AJR Am J Roentgenol. 2012;198(1):207-12. http://dx.doi. org/10.2214/AJR.10.5370. PMid:22194499

72. Kojuri J, Aslani A, Shahrzad S. A large pulmonary artery pseudoaneurysm in a patient with Behcet's disease. J Cardiovasc Med (Hagerstown). 2007;8(12):1073-5. http://dx.doi.org/10.2459/ JCM.0b013e328028fe5e. PMid:18163026

73. Kömürcüoğlu B, Gayaf $M$, Büyüksirin $M$, Celikten E. Case of Behçet's disease presenting with bilateral multiple pulmonary arterial aneurysms. Monaldi Arch Chest Dis. 2003;59(3):216-9. PMid:15065318.

74. Lacombe P, Qanadli SD, Jondeau G, et al. Treatment of hemoptysis in Behçet syndrome with pulmonary and bronchial embolization.J Vasc Interv Radiol. 1997;8(6):1043-7. http://dx.doi org/10.1016/S1051-0443(97)70708-5. PMid:9399476

75. Lê Thi Huong D, Wechsler B, Papo T, et al. Arterial lesions in Behçet's disease. A study in 25 patients. J Rheumatol. 1995;22(11):2103-13. PMid:8596152.

76. Lee JM, Ahn J, Hwang YJ, et al. A case of Behcet's disease complicated with a pulmonary artery aneurysm and deep vein thrombosis, separately. J Rheum Dis. 2013;20(1):52-5. http:// dx.doi.org/10.4078/jrd.2013.20.1.52.

77. Lee SW, Lee SY, Kim KN, Jung JK, Chung WT. Adalimumab treatment for life threatening pulmonary artery aneurysm in Behçet disease: a case report. Clin Rheumatol. 2010;29(1):91-3. http://dx.doi.org/10.1007/s10067-009-1272-2. PMid:19816754

78. Leibowitz D, Planer D, Chajek-Shaul T. Echocardiographic manifestations of Adamantiades-Behcet's disease. Eur J Echocardiogr. 2007;8(6):457-62. http://dx.doi.org/10.1016/j. euje.2006.07.013. PMid:17011238

79. Loh H, Yung G, Bui C, Mansberg R, Comsa M. Pulmonary artery aneurysm with false-positive FDG PET in a patient with Behcet disease. Clin Nucl Med. 2010;35(4):286-8. http://dx.doi. org/10.1097/RLU.0b013e3181d18f21. PMid:20305427

80. Lohani S, Niven R. Images in clinical medicine. Bilateral pulmonary-artery aneurysms in Behcet's syndrome. N Engl J Med. 
2005;353(4):400. http://dx.doi.org/10.1056/NEJMicm041070. PMid:16049212

81. Louali FE, Tamdy A, Soufiani A, et al. Cardiac thrombosis as a manifestation of Behçet syndrome. Tex Heart Inst J. 2010;37(5):568-71. PMid:20978571.

82. Mahendran C, Singh P, Mani NB, Jindal SK. Successful treatment of pulmonary artery aneurysms secondary to possible Behçet's disease. Respiration. 2002;69(4):355-8. http://dx.doi. org/10.1159/000063262. PMid:12169752

83. Malik KJ, Weber SL, Sohail S, Balaan MR. Hilar mass and papilledema on presentation. Chest. 1998;113(1):227-9. http:// dx.doi.org/10.1378/chest.113.1.227. PMid:9440594

84. Marchiori E, Zanetti G, Mano CM. Fulminant evolution of Behçet disease. AJR Am J Roentgenol. 2010;195(4):W311-2. http://dx.doi. org/10.2214/AJR.10.4602. PMid:20858797

85. Marzban M, Mandegar MH, Karimi A, et al. Cardiac and great vessel involvement in "Behcet's disease". J Card Surg. 2008;23(6):765-8. http://dx.doi.org/10.1111/j.15408191.2008.00607.x. PMid:19017008

86. Maurer B, Hensel M, Max R, Fiehn C, Ho AD, Lorenz HM. Autologous haematopoietic stem cell transplantation for Behcet's disease with pulmonary involvement: analysis after 5 years of follow up. Ann Rheum Dis. 2006;65(1):127-9. http:// dx.doi.org/10.1136/ard.2005.035410. PMid:15919675

87. Meshksar A, Farahangiz S, Assadsangabi R, Nabavizadeh SA. Bilateral pulmonary artery involvement in Behcet's yndrome (a case report). Iran J Radiol. 2008;5(S1):7-8.

88. Modaghegh $\mathrm{MH}$, Kazemzadeh $\mathrm{GH}$, Jokar $\mathrm{MH}$. A case of Behçet disease with pulmonary artery pseudoaneurysm: long term follow-up. East Mediterr Health J. 2010;16(3):346-9. PMid:20795454.

89. Mouas H, Lortholary O, Lacombe P, et al. Embolization of multiple pulmonary arterial aneurysms in Behçet's disease. Scand J Rheumatol. 1996;25(1):58-60. http://dx.doi. org/10.3109/03009749609082670. PMid:8774558

90. Nemattallah W. Pulmonary artery aneurysms in patient with Behcet's. MyPACS.net: Radiology Teaching Files: Case 5175797. 2009 Dec [cited 2013 July 04]. http://www.mypacs.net/cases/ PULMONARY-ARTERY-ANEURYSMS-IN-PATIENT-WITHBEHCETS-5175797.html.

91. Ozcan H, Aytac SK, Yagmurlu B, Kaya A. Color Doppler examination of a regressing pulmonary artery pseudoaneurysm due to Behçet disease. J Ultrasound Med. 2002;21(6):697-700. PMid:12054310.

92. Ozen S, Bilginer Y, Besbas N, Ayaz NA, Bakkaloglu A. Behçet disease: treatment of vascular involvement in children. Eur J Pediatr. 2010;169(4):427-30. http://dx.doi.org/10.1007/s00431009-1040-y. PMid:19756733

93. Ozge C, Calikoğlu M, Yildiz A, Türsen U, Tamer L. Bilateral pulmonary artery aneurysms with protein $C$ and protein $S$ deficiency in a patient with Behçet's disease. Scand J Rheumatol. 2004;33(1):52-4. http://dx.doi.org/10.1080/03009740310004694. PMid:15124944

94. Ozkaya S, Sahin U, Gumus A, Taşçı F, Cınarka H, Yavuz A. In situ thrombosis in pulmonary arterial aneurysms due to Behçet's disease and efficacy of Immunosuppressive therapy. Multidiscip Respir Med. 2012;7(1):33. http://dx.doi.org/10.1186/2049-69587-33. PMid:23078955

95. Park JY, Park JG, Won JH, Lee JM, Kim NS, Jung TH. Effects of corticosteroid and chlorambucil on multiple pulmonary artery aneurysms in Behcet's syndrome. A case report. J Korean Med Sci. 1995;10(6):470-3. PMid:8924235.
96. Peall AF, Jones SM. Hemoptysis and Behcet's Syndrome. J Rheumatol. 2009;36(4):848-9. http://dx.doi.org/10.3899/ jrheum.080900. PMid:19342723

97. Pereira de Godoy JM, Batigália F. Bilateral pulmonary artery aneurysm associated with bilateral pulmonary thromboembolism, superior vena caval thrombosis, and Chagas' disease-a case report. Angiology. 2000;51(7):609-14. http:// dx.doi.org/10.1177/000331970005100711. PMid:10917587

98. Rutherford RM, O'Keeffe D, Gilmartin JJ. An unusual case of nonspecific interstitial pneumonitis. Respiration. 2004;71(2):202-5. http://dx.doi.org/10.1159/000076687. PMid:15031581

99. Saadoun D, Wechsler B, Desseaux K, et al. Mortality in Behçet's disease. Arthritis Rheum. 2010;62(9):2806-12. http://dx.doi. org/10.1002/art.27568. PMid:20496419

100. Saba D, Saricaoğlu H, Bayram AS, et al. Arterial lesions in Behçet's disease. Vasa. 2003;32(2):75-81. http://dx.doi.org/10.1024/03011526.32.2.75. PMid:12945099

101. Sacré K, Ducrocq G, Hernigou A, Laissy JP, Papo T. Unusual cardiovascular events in Behçet's disease. Clin Exp Rheumatol. 2010;28(4, Suppl 60):S82-5. PMid:20868577.

102. Sahin AA, Kalyoncu AF, Selçuk ZT, Cöplü L, Celebi C, Baris YI. Behcet's disease with half and half nail and pulmonary artery aneurysm. Chest. 1990;97(5):1277. http://dx.doi.org/10.1378/ chest.97.5.1277a. PMid:2331944

103. Santana AN, Antunes T, Barros JM, Kairalla RA, Carvalho CR Barbas CS. [Pulmonary involvement in Behcet's disease: a positive single-center experience with the use of immunosuppressive therapy]. J Bras Pneumol. 2008;34(6):362-6. PMid:18622502.

104. Schreiber BE, Noor N, Juli CF, Haskard DO. Resolution of Behçet's syndrome associated pulmonary arterial aneurysms with infliximab. Semin Arthritis Rheum. 2011;41(3):482-7. http:// dx.doi.org/10.1016/j.semarthrit.2011.02.006. PMid:21546064

105. Sirmali M, Aloğlu HV, Ozçakar L, Kaya S. Bilateral giant pulmonary artery aneurysms early in Behçet's disease. Eur J Cardiothorac Surg. 2003;24(6):1033. http://dx.doi.org/10.1016/ S1010-7940(03)00614-6. PMid:14643828

106. Steward MJ, D'Cruz DP, Lang-Lazdunski L, Chambers J. Fever, haemoptysis and a mass in the heart. J R Soc Med. 2007;100(2):105-6. http://dx.doi.org/10.1258/jrsm.100.2.105. PMid:17277285

107. Takahama M, Yamamoto R, Nakajima R, Tada H. Successfu surgical treatment of pulmonary artery aneurysm in Behçet's syndrome. Interact Cardiovasc Thorac Surg. 2009;8(3):390-2 http://dx.doi.org/10.1510/icvts.2008.194647. PMid:19064583

108. Tolosa-Vilella C, Capela CA, Monteagudo-Jiménez M, MaríAlfonso B. Infliximab for life-threatening pulmonary artery aneurysms in Behçet's disease. A case report. Clin Exp Rheumatol. 2011;29(4, Suppl 67):S94-5. PMid:21385550.

109. Tunaci M, Ozkorkmaz B, Tunaci A, Gül A, Engin G, Acunaş B. $C T$ findings of pulmonary artery aneurysms during treatment for Behçet's disease. AJR Am J Roentgenol. 1999;172(3):729-33. http://dx.doi.org/10.2214/ajr.172.3.10063870. PMid:10063870

110. Tüzün $\mathrm{H}$, Hamuryudan $V$, Yildirim $S$, et al. Surgical therapy of pulmonary arterial aneurysms in Behçet's syndrome. Ann Thorac Surg. 1996;61(2):733-5. http://dx.doi.org/10.1016/00034975(95)00913-2. PMid:8572805

111. Uh S, Kim JO, You YK, Moon SH, Park CS. A case of Behçet's disease combined with pulmonary artery aneurysm in a Korean female patient. Korean J Intern Med. 1994;9(1):47-50. PMid:8038147. 
112. Vansteenkiste JF, Peene P, Verschakelen JA, van de Woestijne $\mathrm{KP}$. Cyclosporin treatment in rapidly progressive pulmonary thromboembolic Behçet's disease. Thorax. 1990;45(4):295-6. http://dx.doi.org/10.1136/thx.45.4.295. PMid:2356556

113. Vivante A, Bujanover $Y$, Jacobson J, Padeh S, Berkun $Y$. Intracardiac thrombus and pulmonary aneurysms in an adolescent with Behçet disease. Rheumatol Int. 2009;29(5):5757. http://dx.doi.org/10.1007/s00296-008-0730-5. PMid:18850100

114. Wu CT, Lim KE. An unusual cause of large thrombosed pulmonary artery aneurysms associated with chronic thromboembolism. Tzu Chi Med J. 2006;18(3):205-9.

115. Yakut $\mathrm{ZI}$, Odev K. Pulmonary and cardiac involvement in Behçet disease: 3 case reports. Clin Appl Thromb Hemost. 2007;13(3):318-22. http://dx.doi.org/10.1177/1076029607302437. PMid:17636195

116. Yeung PHJ, Lau KKP, Lac A. Behçet's disease with resolving pulmonary artery aneurysm and intracardiac thrombus. Hong Kong J Radiol. 2011;14:167-9.

117. Yilmaz S, Cimen KA. Pulmonary artery aneurysms in Behçet's disease. Rheumatol Int. 2010;30(10):1401-3. http://dx.doi. org/10.1007/s00296-009-1092-3. PMid:19693504

118. Yoon YH, Kim KH, Baek WK, et al. Pulmonary artery pseudoaneurysm in a patient with Behçet disease. J Thorac Cardiovasc Surg. 2004;127(2):590-2. http://dx.doi.org/10.1016/j. jtcvs.2003.09.043. PMid:14762379

119. Hamzaoui K, Berraies A, Kaabachi W, Ammar J, Hamzaoui A. Pulmonary manifestations in Behçet disease: impaired natural killer cells activity. Multidiscip Respir Med. 2013;8(1):29. http:// dx.doi.org/10.1186/2049-6958-8-29. PMid:23556512

120. Hamuryudan V, Oz B, Tüzün H, Yazici $H$. The menacing pulmonary artery aneurysms of Behçet's syndrome. Clin Exp Rheumatol. 2004;22(4, Suppl 34):S1-3. PMid:15515774.
121. Calamia KT, Schirmer M, Melikoglu M. Major vesse involvement in Behçet's disease: an update. Curr Opin Rheumatol. 2011;23(1):24-31. http://dx.doi.org/10.1097/ BOR.0b013e3283410088. PMid:21124084

122. Sayin AG, Vural FS, Bozkurt AK, Oz B, Uygun N. Right atrial thrombus mimicking myxoma and bilateral pulmonary artery aneurysms in a patient with Behçet's disease-a case report. Angiology. 1993;44(11):915-8. http://dx.doi. org/10.1177/000331979304401111. PMid:8239064

Correspondence Shi-Min Yuan

Department of Cardiothoracic Surgery, The First Hospital of Putian, Teaching Hospital, Fujian Medical University 389 Longdejing Street - Chengxiang District Putian 351100, Fujian Province, People's Republic of China Tel.: 865946923117 E-mail:shi_min_yuan@yahoo.com

Author information

S-MY is a cardiac surgeon at The First Hospital of Putian, Teaching Hospital, Fujian Medical University.

Author contribution Conception and design: S-MY Analysis and interpretation: S-MY

Data collection: S-MY Writing the article: S-MY Critical revision of the article: S-MY Final approval of the article*: S-MY Statistical analysis: S-MY Overall responsibility: S-MY Obtained funding: None

*The author have read and approved of the final version of the article submitted to I Vasc Bras. 